\title{
Ocurrence of Vibrio spp., positive coagulase staphylococci and enteric bacteria in oysters (Crassostrea gigas) harvested in the south bay of Santa Catarina island, Brazil
}

\author{
Ocorrência de Vibrio spp., estafilococos coagulase positivo e bactérias entéricas em ostras \\ (Crassostrea gigas) cultivadas na baía sul da ilha de Santa Catarina, Brasil
}

\author{
Roberta Juliano RAMOS ${ }^{1 \star}$, Murilo Anderson PEREIRA ${ }^{1}$, Letícia Adélia MIOTTO'1, \\ Renata D’Aquino FARIA ${ }^{1}$, Nelson SILVEIRA JUNIOR ${ }^{2}$, Cleide Rosana Werneck VIEIRA ${ }^{1}$
}

\begin{abstract}
The aim of this study was to assess the contamination of oysters (Crassostrea gigas), harvested in six different regions of the South Bay of Santa Catarina Island, with Coliforms at $45^{\circ} \mathrm{C}$, Escherichia coli, Vibrio spp., positive coagulase staphylococci, and Salmonella sp. over a period of one year. One hundred eighty oyster samples were collected directly from their culture sites and analyzed. Each sample consisted of a pool of 12 oysters. All of the samples analyzed showed absence of Salmonella, 18 (10\%) samples showed presence of Escherichia coli, 15 (8.3\%) samples were positive for $V$. alginolyticus, and Vibrio cholerae was detected in 4 samples $(2.2 \%)$. The counts of positive-coagulase staphylococci varied from $<10$ to $1.9 \times 10^{2} \mathrm{CFU} . \mathrm{g}^{-1}$, whereas the counts of Coliforms at $45^{\circ} \mathrm{C}$ and $\mathrm{E}$. coli ranged from $<3$ to $1.5 \times 10^{2} \mathrm{MPN} . \mathrm{g}^{-1}$ and $<3$ and $4.3 \times 10 \mathrm{MPN} . \mathrm{g}^{-1}$, respectively. Counts of $V$. parahaemolyticus and $V$. vulnificus ranged between $<3$ and $7 \mathrm{MPN} . \mathrm{g}^{-1}$, for both microorganisms. This suggests the need for monitoring these vibrios contamination in oysters. Based on the results of the microbiological assays, the samples analyzed showed acceptable bacteriological quality, i.e., they were within the parameters established by Brazilian Legislation.
\end{abstract}

Keywords: microbiological quality; bivalve mollusks; filter-feeders; Escherichia coli; Vibrio parahaemolyticus; Vibrio vulnificus.

\begin{abstract}
Resumo
O objetivo deste estudo foi avaliar a contaminação de ostras (Crassostrea gigas) cultivadas em diferentes regiões da Baía Sul da Ilha de Santa Catarina, por coliformes a $45^{\circ} \mathrm{C}$, Escherichia coli, Vibrio spp. Estafilococos coagulase positiva e Salmonella sp., durante o período de um ano. Foram analisadas 180 amostras, coletadas diretamente no local de cultivo. Todas as amostras analisadas apresentaram ausência de Salmonella, 18 (10\%) amostras apresentaram presença de Escherichia coli, 15 (8,3\%) amostras positivas para Vibrio alginolyticus e V. cholerae foi detectado em 4 amostras $(2,2 \%)$. As contagens de Estafilococos coagulase positiva variaram de $<10$ a $1,9 \times 10^{2}$ UFC. ${ }^{-1}$, enquanto que as contagens de coliformes a $45^{\circ} \mathrm{C}$ e E. coli variaram de $<3$ a $1,5 \times 10^{2} \mathrm{NMP}^{-1}$ e $<3$ e 4,3 $\times 10 \mathrm{NMP}^{-g^{-1}}$, respectivamente. As contagens de $V$. parahaemolyticus e $V$. vulnificus variaram de $<3$ a $7 \mathrm{NMP}^{-1}{ }^{-1}$, para ambos os microrganismos, sugerindo um monitoramento tanto destas espécies quanto da temperatura das águas marinhas nas regiões de cultivo. Com base nos resultados das análises microbiológicas, as amostras analisadas mostraram qualidade bacteriológica aceitável, ou seja, dentro dos parâmetros estabelecidos na legislação brasileira.

Palavras-chave: qualidade microbiológica; moluscos bivalves; filtradores; Escherichia coli; Vibrio parahaemolyticus; Vibrio vulnificus.
\end{abstract}

\section{Introduction}

In Brazil, bivalve mollusks production takes place mainly in Santa Catarina State, south Brazil, due to the excellent geographical conditions of this area for marine organism cultures, such as the presence of a large number of bays facilitating the establishment of mollusk farms (COELHO et al., 2003; CORRÊA et al., 2007; OLIVEIRA NETO, 2005). In 2007, about $11.000 \mathrm{t}$ of mollusks were commercialized in Santa Catarina State, the largest producing region of oysters (Crassostrea gigas). The major production takes place in sea farms located in the South Bay of Santa Catarina Island (OLIVEIRA NETO, 2007).

Oysters are filter-feeders that efficiently concentrate microorganisms from polluted habitats, and because they are often consumed raw, they pose a health risk to consumers
(CORRÊA et al., 2007; LALOO et al., 2000; PEREIRA et al., 2006; SILVA et al., 2004). The enteric bacteria, originating from the contamination of water with human residues, can readily contaminate the fauna in marine environments, especially molluscan shellfish (CORRÊA et al., 2007, PEREIRA et al., 2006). To guarantee sanitary quality, mollusk cultures should be monitored for contamination by pathogenic microorganisms (CORRÊA et al., 2007).

Vibrios are very common in marine and estuarine water environments and some may cause infections in humans that were exposed to seafood or sea water. Several Vibrio species are pathogenic to humans and may be present in raw or partially cooked shellfish (LHAFI; KÜHNE, 2007; PEREIRA et al., $2007 \mathrm{a}, \mathrm{b})$. The concentration of Vibrio spp. in oysters is directly

\section{Received 15/8/2010}

Accepted 28/2/2012 (004990)

Departamento de Ciência e Tecnologia de Alimentos - CAL, Centro de Ciências Agrárias - CCA, Universidade Federal de Santa Catarina - UFSC, Rod. Admar Gonzaga,

1346, CEP 88034-001, Itacorubi, Florianópolis, SC, Brasil, e-mail: robertajulianoramos@yahoo.com.br

2 Associação de Maricultores do Sul da Ilha (AMASI), Florianópolis, SC/Brasil

${ }^{*}$ Corresponding author 
related to water temperature, with a higher concentration being present in oysters from warm water and outbreaks occurring usually during summer months (CABRERA-GARCIA; VASQUEZ-SALINAS; QUINONES-RAMIREZ, 2004; PEREIRA; VIANA; RODRIGUES, 2004; PEREIRA et al., 2007a; YOON et al., 2008). However, no close correlation has been noted between microorganisms of fecal origin and vibrios that are potentially pathogenic for humans (NORMANNO et al., 2006; OLIVER; WARNER; CLELAND, 1983).

In this context, the aim of this study was to assess the contamination of oysters (Crassostrea gigas), harvested in six different regions of the South Bay of Santa Catarina Island, with Coliforms at $45^{\circ} \mathrm{C}$, Escherichia coli, Vibrio spp., positive coagulase staphylococci, and Salmonella sp., over a period of one year.

\section{Materials and methods}

\subsection{Sample collection and preparation}

The collection sites studied are located in six different geographical regions in the district of Ribeirão da Ilha, in the South Bay of Santa Catarina Island: Caieira da Barra do
Sul (27 $48^{\prime} 849^{\prime}$ 'S and $\left.48^{\circ} 33^{\prime} 981^{\prime \prime} \mathrm{W}\right)$; Tapera do Ribeirão ( $27^{\circ} 46^{\prime} 989^{\prime \prime} \mathrm{S}$ and $48^{\circ} 34318^{\prime \prime} \mathrm{W}$ ); Costeira do Ribeirão ( $27^{\circ} 44^{\prime} 350^{\prime \prime} \mathrm{S}$ and $\left.48^{\circ} 33^{\prime} 890^{\prime \prime} \mathrm{W}\right)$; Freguesia do Ribeirão $\left(27^{\circ} 43^{\prime} 17.4^{\prime \prime} \mathrm{S}\right.$ and $\left.48^{\circ} 33^{\prime} 57.8^{\prime \prime} \mathrm{W}\right)$, Barro Vermelho ( $27^{\circ} 42^{\prime} 11.1^{\prime \prime} \mathrm{S}$ and $\left.48^{\circ} 33^{\prime} 33.7^{\prime \prime} \mathrm{W}\right)$, and Tapera da Base Aérea (27 41' 397' $\mathrm{S}$ and $\left.48^{\circ} 34^{\prime} 230^{\prime \prime} \mathrm{W}\right)$, which were identified, respectively, as regions: $\mathrm{A}, \mathrm{B}, \mathrm{C}, \mathrm{D}, \mathrm{E}$, and $\mathrm{F}$ (Figure 1).

The collections were carried out from March 2006 to February 2007, totalizing 15 collections. At each sampling time, the water temperature was recorded. Each pool was composed of 12 oysters. Two samples were collected from each of the six culture areas, totalizing 180 samples over a twelve-month period. The oysters were transported to the Laboratory of Food Microbiology, Department of food Science and Technology at the Federal University of Santa Catarina, in isothermal boxes with packaged potable ice. All specimens were examined within 2 hours of collection.

The oysters were scrubbed under tap water to remove debris, allowed to dry, disinfected with $70 \%$ ethanol, and aseptically opened using a sterilized knife. The flesh and intervalve liquid were aseptically placed in sterile bags, making up the pool of

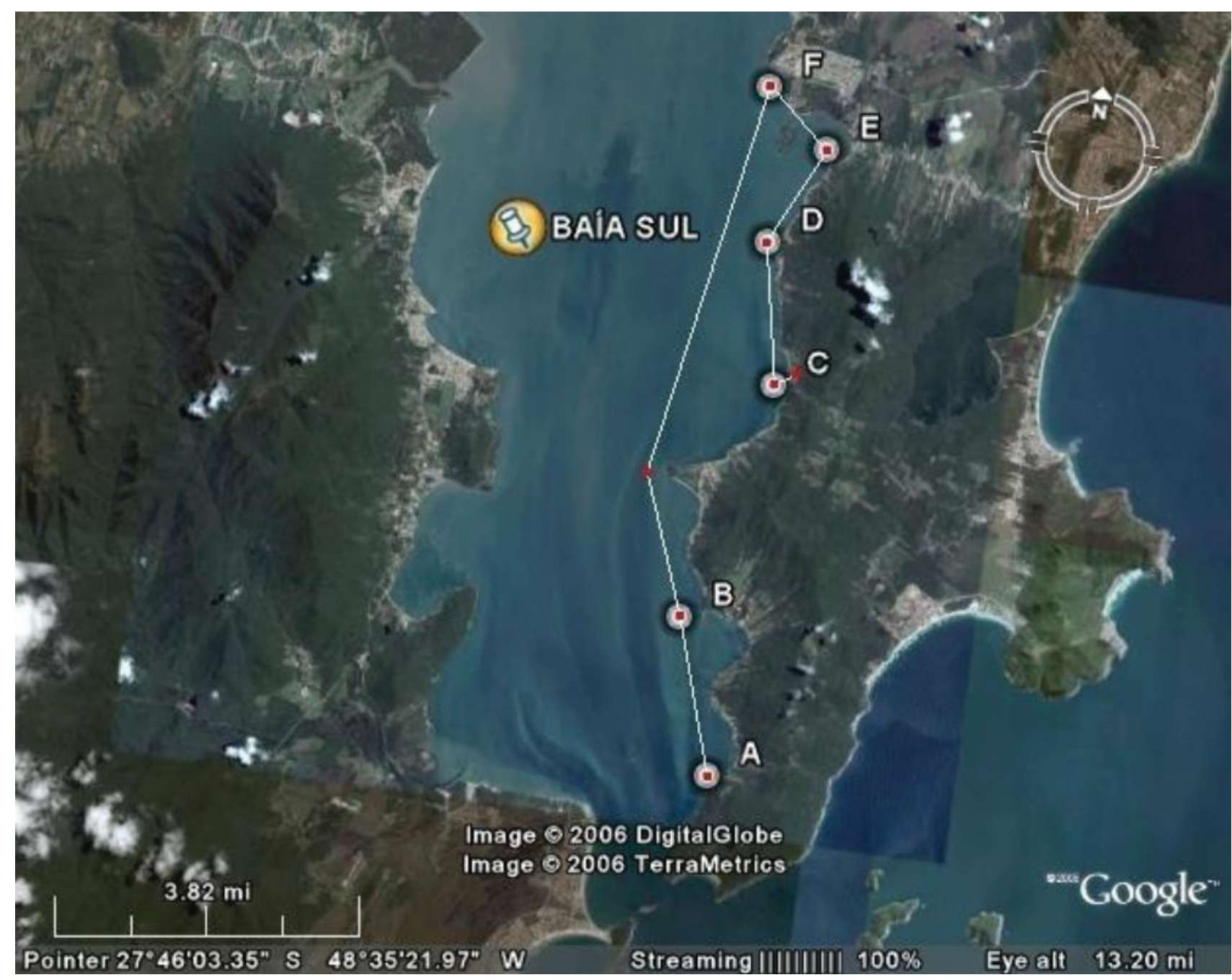

Figure 1. Collection sites in the six different regions at South Bay in Florianopolis, Santa Catarina, Brazil. 
each sample, from which two samples of $25 \mathrm{~g}$ and one sample of $50 \mathrm{~g}$ each were later weighed.

\subsection{Microbiological analysis}

Coliforms at $45{ }^{\circ} \mathrm{C}$ and Escherichia coli were evaluated according to APHA (AMERICAN..., 2001). Twenty-five grams of each sample was weighed, added to $225 \mathrm{~mL}$ of peptone water $0.1 \%$, and homogenized in a Bagmixer blender (Interscience, France). Further dilutions $\left(10^{-2}, 10^{-3}\right)$ were then prepared from this dilution, and $1 \mathrm{~mL}$ of each dilution was inoculated into each tube of a series of three tubes containing Lauryl Sulphate Triptose broth (LST). They were incubated at $35^{\circ} \mathrm{C}\left( \pm 1^{\circ} \mathrm{C}\right)$ for 48 hours. From each tube of LST with turbidity and production of gas, $100 \mu \mathrm{L}$ from the positive tubes were transferred to tubes containing Escherichia coli broth (EC). The tubes of EC were incubated in water bath at $45.0^{\circ} \mathrm{C} \pm 0.5^{\circ} \mathrm{C}$ for 48 hours. The EC tubes showing turbidity and gas production were streaked on Eosin-Methylene Blue Agar (EMB) and incubated at $35^{\circ} \mathrm{C}$ $\left( \pm 1{ }^{\circ} \mathrm{C}\right)$ for 24 hours. The typical colonies of Escherichia coli were submitted to the following biochemical tests: Indole, Methyl Red, Voges Proskauer, and Citrate (IMViC). The final result of coliforms at $45^{\circ} \mathrm{C}$ was obtained from the table of the Most Probable Number (MPN) by the combination of the number of positive tubes, i.e., those showing turbidity and gas production; while the counts of E. coli were performed from the biochemical confirmation of the typical colonies isolated in the test IMViC, also obtained by the positive isolated combination from the MPN table.

Positive coagulase staphylococci was evaluated according to APHA (AMERICAN..., 2001). Twenty-five grams of the sample was weighed, added to $225 \mathrm{~mL}$ of peptone water $0.1 \%$, and homogenized in a Bagmixer blender (Interscience, France). Further dilutions $\left(10^{-2}, 10^{-3}\right)$ were then prepared from this dilution. From each one of these first three dilutions, $1 \mathrm{~mL}$ was distributed into 3 Baird Parker agar plates (BP), which were incubated at $35^{\circ} \mathrm{C}\left( \pm 1{ }^{\circ} \mathrm{C}\right)$ for 48 hours. Three typical colonies were subcultured for Brain-Heart Infusion broth (BHI) and incubated at $35^{\circ} \mathrm{C}\left( \pm 1^{\circ} \mathrm{C}\right)$ for 24 hours for catalase and coagulase tests. The results were expressed as coagulase-positive staphylococci/g. When the coagulase reaction was negative, the result was expressed as $<10$ Colony Forming Units per gram of sample (CFU.g $\left.{ }^{-1}\right)$.

For detection of Salmonella sp. (AMERICAN..., 2001), a pre-enrichment of $25 \mathrm{~g}$ of sample was performed in $225 \mathrm{~mL}$ of buffered peptone water (BPW) which was incubated at $35^{\circ} \mathrm{C}$ $\left( \pm 1^{\circ} \mathrm{C}\right)$ for 24 hours. After 24 hours of pre-enrichment, aliquots were transferred simultaneously to tetrathionate broth (TTB) and Rappaport-Vassiliadis broth (RV) and were incubated at $42{ }^{\circ} \mathrm{C}\left( \pm 1^{\circ} \mathrm{C}\right)$ for 24 hours. The selective enrichment cultures were streaked onto the surface of Brilliant-green Phenol-red Lactose Sucrose (BPLS) and Xylose Lysine Deoxycholate (XLD) agars, and they were incubated at $35^{\circ} \mathrm{C}\left( \pm 1^{\circ} \mathrm{C}\right)$ for 24 hours. The typical colonies of Salmonella sp. were submitted to biochemical screening in triple sugar iron agar (TSI), lysine iron agar (LIA), and urea agar (UA). Colonies suspected of being Salmonella sp. were analyzed by complementary biochemical tests: Dulcitol,
Indole, Malonate, MRVP - Methyl Red Voges Proskauer, and Citrate.

Vibrio spp. was evaluated according to Kaysner and De Paola Junior(2001). $50 \mathrm{~g}$ of the sample was weighed, $450 \mathrm{~mL}$ phosphate buffered saline (PBS) were added, and the mixture was homogenized using a Bagmixer blender. Decimal dilutions up to $10^{-4}$ were prepared from this dilution, and $1 \mathrm{~mL}$ of each dilution was inoculated into one tube of a series of three tubes containing alkaline peptone water (APW) for the enumeration of the Vibrio parahaemolyticus and Vibrio vulnificus using the most probable number (MPN) method, as described in the US Food and Drug Administration Bacterial Analytical Manual (KAYSNER; DE PAOLA JUNIOR, 2001). After 18 hours of incubation at $35{ }^{\circ} \mathrm{C}\left( \pm 1^{\circ} \mathrm{C}\right)$, a loopful of the tubes showing growth were streaked onto thiosulfate-citratebile-sals-sucrose agar (TCBS) plates and incubated at $35{ }^{\circ} \mathrm{C}$ $\left( \pm 1^{\circ} \mathrm{C}\right.$ ) for $18-24$ hours. Both sucrose-positive (yellow on TCBS agar) and sucrose-negative (blue-green on TCBS agar) colonies were submitted for confirmation as gram-negative and oxidase-positive. Further biochemical differentiation for identification and confirmation of isolated items were performed using the API 20E system (bioMérieux).

\subsection{Statistical analysis}

Since the detection of Salmonella sp., V. cholerae and $V$. alginolyticus was not quantitative, the results were expressed as isolation percentage using the presence or absence of these bacteria in each sample. Coliforms at $45^{\circ} \mathrm{C}$, Escherichia coli, $V$. parahaemolyticus, and V. vulnificus were expressed as isolation percentage and as MPN enumeration. The results for the $V$. parahaemolyticus and V. vulnificus isolation were then statistically analyzed to observe any correlation between the presence of vibrios and water temperature. Differences in the incidence of the Vibrio spp. in oysters in different seasons of the year were evaluated by ANOVA ( $p<0.05)$, and mean differences were evaluated using Tukey's test. Statistical analyses of the data were performed with the Statistica ${ }^{\oplus} 6.0$ software.

\section{Results and discussion}

The counts of coliforms at $45^{\circ} \mathrm{C}$ in the oysters ranged from $<3$ to $1.5 \times 10^{2} \mathrm{MPN}^{-1}{ }^{-1}$, and $147(81.6 \%)$ samples showed counts equal to $<3 \mathrm{MPN} \cdot \mathrm{g}^{-1}$. The highest count was seen in the month of December, in region B; however, region E showed higher number of positive samples for Coliforms at $45^{\circ} \mathrm{C}$ in relation to the other areas (Table 1).

Only one $(0.6 \%)$ sample showed high values of MPN for Coliforms at $45^{\circ} \mathrm{C}$ exceeding the limit allowed by the Resolution $12 / 2001$. The Department of Sanitary Vigilance has determined the maximum acceptable level of $1 \times 10^{2} \mathrm{MPN}$ per gram of Coliforms at $45^{\circ} \mathrm{C}$ in raw seafood-based dishes (BRASIL, 2001). Although oysters are not mentioned explicitly in this paragraph, they may be considered raw seafood since they are traditionally consumed in natura.

Pereira et al., 2006 found levels of contamination for Coliforms at $45{ }^{\circ} \mathrm{C}$ in oysters Crassostrea gigas from the culture area in Ribeirão da Ilha, in South Bay, with counts 
Table 1. Counting and isolation percentage Coliforms at $45^{\circ} \mathrm{C}$, Escherichia coli, Vibrio parahaemolyticus, and Vibrio vulnificus in the 15 collection oysters in six different regions of the South Bay of Santa Catarina Island.

\begin{tabular}{|c|c|c|c|}
\hline Microorganisms region (n) & Minimum counting & Maximum counting & Positive samples \\
\hline Coliforms $45^{\circ} \mathrm{C}$ & $\left(\mathrm{MPN} \cdot \mathrm{g}^{-1}\right)^{\mathrm{a}}$ & $\left(\mathrm{MPN} \cdot \mathrm{g}^{-1}\right)^{\mathrm{a}}$ & $\mathrm{n}(\%)$ \\
\hline $\mathrm{A}(30)$ & $<3.0$ & 4.0 & $2(6.7)$ \\
\hline $\mathrm{B}(30)$ & $<3.0$ & $1.5 \times 10^{2}$ & $4(13.3)$ \\
\hline $\mathrm{C}(30)$ & $<3.0$ & 4.0 & $2(6.7)$ \\
\hline $\mathrm{D}(30)$ & $<3.0$ & 9.0 & $9(30.0)$ \\
\hline $\mathrm{E}(30)$ & $<3.0$ & $9.3 \times 10$ & $12(40.0)$ \\
\hline A (30) & $<3.0$ & $<3.0$ & Zero $(0.0)$ \\
\hline $\mathrm{B}(30)$ & $<3.0$ & 9.0 & $3(10.0)$ \\
\hline $\mathrm{C}(30)$ & $<3.0$ & 4.0 & $1(3.3)$ \\
\hline $\mathrm{D}(30)$ & $<3.0$ & 9.0 & $4(13.3)$ \\
\hline $\mathrm{E}(30)$ & $<3.0$ & 9.0 & $8(26.7)$ \\
\hline $\mathrm{B}(30)$ & $<3.0$ & $<3.0$ & Zero $(0.0)$ \\
\hline $\mathrm{C}(30)$ & $<3.0$ & $<3.0$ & Zero $(0.0)$ \\
\hline $\mathrm{D}(30)$ & $<3.0$ & 4.0 & $2(6.7)$ \\
\hline $\mathrm{E}(30)$ & $<3.0$ & 3.0 & $3(10.0)$ \\
\hline $\mathrm{F}(30)$ & $<3.0$ & 7.0 & $2(6.7)$ \\
\hline Vibrio vulnificus & $\left(\mathrm{MPN} \cdot \mathrm{g}^{-1}\right)^{\mathrm{a}}$ & $\left(\mathrm{MPN} \cdot \mathrm{g}^{-1}\right)^{\mathrm{a}}$ & n (\%) \\
\hline $\mathrm{A}(30)$ & $<3.0$ & 4.0 & $2(6.7)$ \\
\hline B (30) & $<3.0$ & $<3.0$ & Zero $(0.0)$ \\
\hline $\mathrm{C}(30)$ & $<3.0$ & 6.0 & $2(6.7)$ \\
\hline $\mathrm{D}(30)$ & $<3.0$ & $<3.0$ & Zero $(0.0)$ \\
\hline $\mathrm{E}(30)$ & $<3.0$ & 4.0 & $3(10.0)$ \\
\hline $\mathrm{E}(30)$ & $<10.0$ & $3.0 \times 10$ & $2(6.7)$ \\
\hline $\mathrm{F}(30)$ & $<10.0$ & 3. $0 \times 10$ & $2(6.7)$ \\
\hline
\end{tabular}

Note: ${ }^{a} \mathrm{MPN} \cdot \mathrm{g}^{-1}=$ most probable number per gram $;{ }^{\mathrm{b}} \mathrm{CFU} \cdot \mathrm{g}^{-1}=$ Colony forming unit/gram of sample.

that ranged between $<3$ and $9.3 \times 10 \mathrm{MPN} \cdot \mathrm{g}^{-1}$, and $73 \%$ of the samples showed counts equal to $<3 \mathrm{MPN} \cdot \mathrm{g}^{-1}$. Such levels are similar to those obtained in this study. Silva et al. (2004), evaluating the microbiological quality of mangrove oysters (Crassostrea rhizophorae), collected at a natural oyster bed in the estuary of Cocó river in Fortaleza, Ceará, Brazil, found higher levels for Coliforms a $45^{\circ} \mathrm{C}$ than those observed in the present study, ranged from $<1.8$ to $9.2 \times 10^{2} \mathrm{MPN}^{-g^{-1}}$. In a study carried out by Téllez et al. (1999), monitoring the quality of oysters (Crassostrea virginica) cultivated in the state of Tamaulipas, Mexico, low counts of Coliforms at $45^{\circ} \mathrm{C}$ with highest counts of $1.4 \times 10 \mathrm{MPN} .100 \mathrm{~g}^{-1}$ were found.

Since $E$. coli is a better indicator of fecal contamination than the other genres and species of the coliforms group, determination of its incidence in a coliform population is desirable (JAY, 2005). The counts of E. coli obtained in the oysters from the six different regions were low, ranging between $<3$ and $4.3 \times 10 \mathrm{MPN} \cdot \mathrm{g}^{-1}$, and $162(90 \%)$ samples showed counts below detectable levels $\left(<3 \mathrm{MPN} \cdot \mathrm{g}^{-1}\right)$. In a study carried out by Oliveira et al. (2006), monitoring the quality of oysters Crassostrea gigas cultivated in Alaska, USA, the count of E. coli

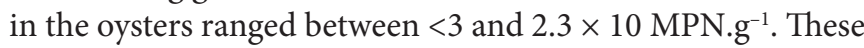
results are very similar to those obtained in this present study. In a study performed by Pereira et al. (2006), E. coli was found in $9 \%$ of the samples of oysters Crassostrea gigas collected in three different culture areas in Florianópolis, State of Santa Catarina. Such results are in agreement with the results shown in this study, with 18 (10\%) positive samples (Table 1); however, this study showed lower numbers than the maximum allowed by Brazilian legislation for Coliforms at $45^{\circ} \mathrm{C}$. 
Region E showed the highest levels of E. coli and Coliforms at $45^{\circ} \mathrm{C}$ in the mollusks, eight (26.7\%) samples were contaminated, probably due the higher population density and geographical characteristics of this region, while region A did not show any sample contaminated by E. coli (Table 1). It is interesting to point out that, although the region $\mathrm{E}$ showed the highest frequency of contaminated samples for all researched microorganisms, cell counts were very low, i.e., well below the limits established by legislation.

The counts of positive coagulase staphylococci in the samples ranged between $<10$ and $1.9 \times 10^{2} \mathrm{CFU}^{-1}$ of sample (Table 1); the highest counts obtained in regions $\mathrm{C}, \mathrm{D}$, and $\mathrm{E}$ were registered in the month of September. This did not happen in the other regions although no significant statistical differences were observed at a level of significance of $5 \%$, between the averages of counts of positive coagulase staphylococci in the different regions studied ( $\mathrm{H}: 2.1008 ; \mathrm{p}>0.05$ ).

All the samples analyzed are within the limits established by the RDC 12/2001 - ANVISA, which has determined a maximum count of $10^{3} \mathrm{CFU} . \mathrm{g}^{-1}$ of positive coagulase staphylococcus for in natura bivalve mollusks (BRASIL, 2001). The samples analyzed also showed counts well below these limits. According to Jay (2005), the presence of Staphylococcus can be expected, even if in small amounts, in almost all foods of animal origin.

Pereira et al. (2006), evaluating 45 samples of oysters from culture areas located in Florianópolis, found only one sample contaminated by positive coagulase staphylococci, while Ayulo, Machado and Scussel (1994), evaluating samples of bivalve mollusks from coastal regions of Santa Catarina, detected the presence of Staphylococcus aureus in 60\% of the samples. In this present study, about $8 \%(14 / 180)$ of the samples showed contamination by positive coagulase staphylococci.

All of the 180 samples analyzed showed absence of Salmonella sp., complying with the current legislation, RDC 12/2001 - ANVISA, which has established the absence of Salmonella sp. in in natura, refrigerated or frozen bivalve mollusks (BRASIL, 2001). Pereira et al. (2006) did not find Salmonella sp. in any of the 90 samples analyzed; 30 of which were from the region of Ribeirão da Ilha in the South Bay. Such result is in agreement with those found in this study.

Although Salmonella sp. was not isolated in any of the samples of this study, this bacterium is among the most important cause of foodborne diseases.

Of the 180 samples analyzed, 25 (13.9\%) contained one or more vibrios (Table 2). The most frequently isolated species were V. alginolyticus (15 isolates, 8.3\%), V. vulnificus (9 isolates, $5.0 \%$ ), and Vibrio parahaemolyticus (8 isolates, $4.4 \%$ ). Vibrio cholerae was detected in 4 samples (2.2\%), and Vibrio fluvialis was detected only in one sample (0.6\%). Part of the samples was contaminated with more than one Vibrio species. Two Vibrio species were found in $4.4 \%$ of the samples, and $1.1 \%$ showed a contamination with three Vibrio species. The percentage of the samples containing one or more Vibrio species varied over the investigation period. In the last four summer samplings, it was observed a stronger presence of Vibrio spp. compared with the other seasons of the year $(\mathrm{p}<0.05)$. When the water temperature was at its highest, the highest level of Vibrio-positive samples was found, and positive correlation $(\mathrm{r}=0.51 ; \mathrm{p}<0.01)$ was observed between the incidence of Vibrio spp. in oysters and temperature of marine waters (Figure 2). These findings are in agreement with those of several authors (HLADY; KLONTZ, 1996; LHAFI; KÜHNE, 2007; MATTÉ et al., 1994), who reported a considerable rise in the numbers of Vibrio spp. isolated from seafood samples during the summer months.

Vibrio alginolyticus was the most prevalent species confirming published research findings by authors from other countries, both in Europe and in the United States (LHAFI; KÜHNE, 2007; MATTÉ et al., 1994; RIPABELLI et al., 1999). The counts of $V$. parahaemolyticus and $V$. vulnificus in the samples ranged between $<3$ and $7 \mathrm{MPN}^{-\mathrm{g}^{-1}}$ of sample for both bacteria (Table 1). The Department of Sanitary Vigilance has determined the maximum acceptable level of $10^{3}$ per gram of $V$. parahaemolyticus in raw seafood-based dishes

Table 2. Prevalence of Vibrio spp. in 180 oysters samples from the South Bay of Santa Catarina Island.

\begin{tabular}{|c|c|c|}
\hline \multirow{2}{*}{ Microorganisms } & \multicolumn{2}{|c|}{ Positive samples } \\
\hline & No. & $(\%)$ \\
\hline Vibrio spp. & 25 & 13.9 \\
\hline V. alginolyticus & 7 & 3.9 \\
\hline V. parahaemolyticus & 1 & 0.6 \\
\hline V. vulnificus & 4 & 2.2 \\
\hline V. cholerae & 2 & 1.1 \\
\hline V. alginolyticus and $V$. parahaemolyticus & 3 & 1.7 \\
\hline V. parahaemolyticus and V. vulnificus & 2 & 1.1 \\
\hline V. vulnificus and $V$. alginolyticus & 2 & 1.1 \\
\hline$V$. alginolyticus and V. cholerae & 1 & 0.6 \\
\hline V. fluvialis & 1 & 0.6 \\
\hline $\begin{array}{l}V . \text { vulnificus and } V . \text { alginolyticus and } \\
V \text {. parahaemolyticus }\end{array}$ & 1 & 0.6 \\
\hline $\begin{array}{l}V . \text { cholerae and } V . \text { alginolyticus and } \\
\text { V. parahaemolyticus }\end{array}$ & 1 & 0.6 \\
\hline
\end{tabular}

Temperature $=22.415+1.1058$ * Vibrio incidence

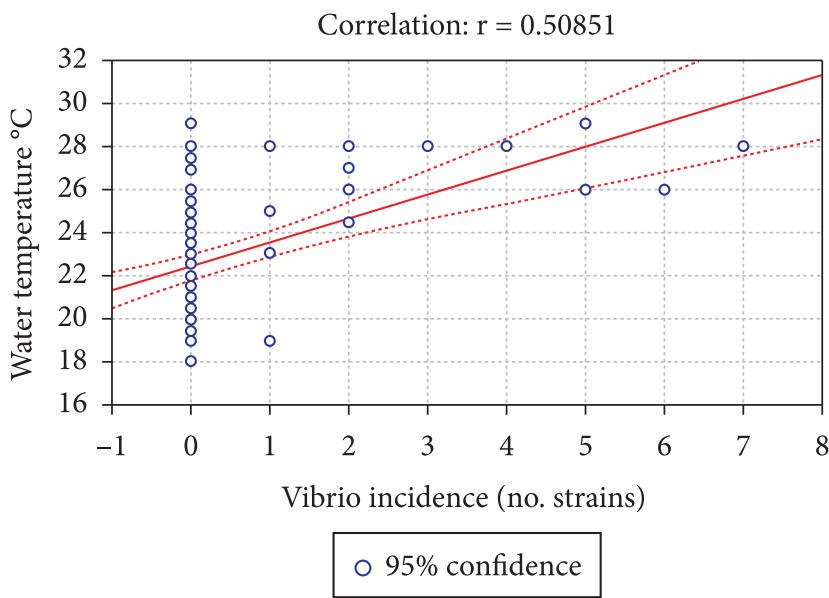

Figure 2. Correlation between incidence of Vibrio spp. in oysters and temperature of marine waters in six different regions of the South Bay of Santa Catarina Island. 
(BRASIL, 2001). Hence, all samples analyzed are within the limits established by Brazilian Legislation. The presence the $V$. vulnificus, even at low counting, indicate need for continuous monitoring of bacterial contamination in oysters.

\section{Conclusion}

The high percentage of samples with counts of coliforms at $45^{\circ} \mathrm{C}$ equal to $<3 \mathrm{MPN} \cdot \mathrm{g}^{-1}$ suggests that the oysters produced in the South Bay show acceptable hygienic and sanitary quality. The great majority of the samples showed absence of E. coli, and in the samples in which the presence of this microorganism was confirmed, the counts were very low. However, since E. coli is the best indicator of recent fecal contamination, and because it is a bacterium which, depending on the species, can be highly pathogenic to humans, the control of this microorganism in oysters, which are frequently consumed raw, is essential.

The counts of positive coagulase staphylococcus in the samples of oysters were well below the limits allowed by the current legislation, RDC 12/2001 - ANVISA, probably due to the fact that the oyster meat is enclosed inside their shells, with no direct contact with the manipulators.

All of the samples analyzed showed absence of Salmonella sp. in $25 \mathrm{~g}$, which, therefore, comply with the standards established by Brazilian legislation, RDC 12/2001 - ANVISA

The results obtained in the present study confirm the needs to improve shellfish-borne disease control strategies focusing on pathogenic vibrios. Therefore, classical fecal indicators are not suitable for oyster quality control by itself. The risk to public health from the presence of vibrios depends on the consumer health and the concentration and pathogenicity of the pathogen.

The safest way to eat oysters is by ensuring they are cooked before consumption.

\section{Acknowledgements}

The authors are grateful to CNPq SECIS/MCT - National Council of Scientific and Technological Development SECIS/ Ministry of Science and Technology, Brazil; the CT-Agro - Fund for the Agribusiness Sector; and CT- Hidro - Fund for the Water Resources Sector for the financial support to the Project: "Hygienic and sanitary monitoring of the culture waters and sea mollusks produced at South Bay, Florianópolis, Santa Catarina", Brazil.

\section{References}

AMERICAN PUBLIC HEALTH ASSOCIATION - APHA. Compendium of Methods for the Microbiological Examination of Foods. 4. ed. Washington, 2001.

AYULO, A. M. R.; MACHADO, R. A.; SCUSSEL, V. M. Enterotoxigenic Escherichia coli and Staphylococcus aureus in fish and seafood from the southern of Brazil. International Journal of Food Microbiology, v. 24, n. 1-2, p. 171-178, 1994. http://dx.doi. org/10.1016/0168-1605(94)90116-3

BRASIL. Resolução RDC no 12 de 02 de janeiro de 2001. Aprova o regulamento técnico princípios gerais para estabelecimento de critérios e padrões microbiológicos para alimentos e seus anexos I,
II e III. Diário Oficial da República Federativa do Brasil, Brasília, DF, 1 jan. 2001.

CABRERA-GARCIA, M. E.; VASQUEZ-SALINAS, C.; QUINONES-RAMIREZ, E. I. Serologic and molecular characterization of Vibrio parahaemolyticus strains isolated from seawater and fish products of Gulf of Mexico. Applied and Environmental Microbiology, v. 70, p. 6401-6406, 2004. PMid:15528498. PMCid:525121. http://dx.doi.org/10.1128/ AEM.70.11.6401-6406.2004

COELHO, C. et al. Hepatitis A virus detection in oysters (Crassostrea gigas) in Santa Catarina State, Brazil, by reverse transcription-polymerase chain reaction. Journal of Food Protection, v. 66, n. 3, p. 507-511, 2003. PMid:12636311.

CORRÊA, A. A. et al. Depuration dynamics of oysters (Crassostrea gigas) artificially contaminated by Salmonella enterica serovar Typhimurium. Marine Environmental Research, v. 63, p. 479-489, 2007. PMid:17280712. http://dx.doi.org/10.1016/j. marenvres.2006.12.002

HLADY, W. G.; KLONTZ, K. C. The epidemiology of Vibrio infections in Florida, 1981-1993. International Journal of Infectious Diseases, v. 173, p. 1176-1183. 1996.

JAY, J.M. Microbiologia de Alimentos. 6. ed. Editora Artmed, 2005.711 p. KAYSNER, C. A.; DE PAOLA JUNIOR, A. Vibrio cholerae, V.parahaemolyticus, V. vulnificus, and Other Vibrio spp. In: UNITED STATES FOOD AND DRUG ADMINSTRATION - US FDA; CENTER FOR FOOD SAFETY \& APPLIED NUTRITION - CFSAN. Bacteriological Analytical Manual Online. 2001. chap 9. Disponível em: <http://www.cfsan.fda.gov>. Acesso em: 10 jul. 2008.

LALOO, S. et al. Bacteriological quality of raw oysters in Trinidad and the attitudes, knowledge and perceptions of the public about its consumption. International Journal of Food Microbiology, v. 54, p. 99-107, 2000. http://dx.doi.org/10.1016/S0168-1605(99)00161-0

LHAFI, S. K.; KÜHNE, M. Occurrence of Vibrio spp. in blue mussels (Mytilus edulis) from the German Wadden Sea. International Journal of Food Microbiology, v. 116, n. 2, p. 297-300, 2007. PMid:17331605. http://dx.doi.org/10.1016/j. ijfoodmicro.2007.01.007

MATTÉ, G. R. et al. Potentially pathogenic vibrios associated with mussels from a tropical region on the Atlantic Coast of Brazil. Journal of applied microbiology, v. 77, p. 201-207, 1994.

NORMANNO, G. et al. Vibrio parahaemolyticus, Vibrio vulnificus and microorganisms of fecal origin in mussels (Mytilus galloprovincialis) sold in the Puglia region (Italy). International Journal of Food Microbiology, v. 106, p. 219-222, 2006. PMid:16226820. http:// dx.doi.org/10.1016/j.ijfoodmicro.2005.05.020

OLIVEIRA NETO, F. M. Diagnóstico do cultivo de moluscos em Santa Catarina. 3. ed. Florianópolis: Epagri, 2005. 67 p.

OLIVEIRA NETO, F. M. Síntese informativa da produção de moluscos (mexilhões, ostras e vieiras) no estado de Santa Catarina em 2006. Florianópolis: Epagri, Cedap, 2007. Disponível em: <http://www.epagri.rct-sc.br/>. Acesso em: 05 maio 2007.

OLIVEIRA, A. C. M. et al. Quality of alaskan maricultures oysters (Crassostrea gigas): a one-year survey. Journal of Food Science, v. 71, n. 9, p. 532-543, 2006. http://dx.doi.org/10.1111/j.17503841.2006.00186. $\mathrm{x}$

OLIVER, J. D.; WARNER, R. A.; CLELAND, D. R. Distribution of Vibrio vulnificus and other lactose-fermenting vibrios in the marine environments. Applied and Environmental Microbiology, v. 45, p. 985-998, 1983. PMid:6847190. PMCid:242401. 
PEREIRA, C. S.; VIANA, C. M.; RODRIGUES, D. P. Vibrio parahaemolyticus produtores de urease isolados a partir de ostras (Crassostrea rhizophorae) coletadas in natura em restaurantes e mexilhões (Perna perna) de banco natural. Ciência e Tecnologia de Alimentos, v. 24, p. 591-595, 2004. http://dx.doi.org/10.1590/ S0101-20612004000400019

PEREIRA, C. S. et al. Vibrios patogênicos em ostras (Crassostrea rhizophorae) servidas em restaurantes no Rio de Janeiro: um alerta para a Saúde Pública. Revista da Sociedade Brasileira de Medicina Tropical, v. 40, n. 3, p. 300-303, 2007(a). PMid:17653465. http:// dx.doi.org/10.1590/S0037-86822007000300010

PEREIRA, C. S. et al. Vibrio spp. isolados a partir de mexilhões (Perna perna) in natura e pré-cozidos de Estação Experimental de Cultivo, Rio de Janeiro, RJ, Brasil. Ciência e Tecnologia de Alimentos, v. 27, n. 2, p. 387-390, 2007(b). http://dx.doi.org/10.1590/S010120612007000200030

PEREIRA, M. A. et al. Qualidade microbiológica de ostras (Crassostrea gigas) produzidas e comercializadas na região litorânea de Florianópolis. Brazilian Journal of Microbiology, v. 37 , n. 2 , p. $159-163$, 2006. http://dx.doi.org/10.1590/S151783822006000200012

RIPABELLI, G. et al. Occurrence of Vibrio and other pathogenic bacteria in Mytilus galloprovincialis (mussels) harvested from Adriatic Sea, Italy. International Journal of Food Microbiology, v. 49, p. 43-48, 1999. http://dx.doi.org/10.1016/S0168-1605(99)00056-2

SILVA, A. I. M. et al. Bacteria of fecal origin in mangrove oysters (Crassostrea rhizophorae) in the Cocó river estuary, Ceará State, Brazil. Brazilian Journal of Microbiology, v. 35, n. 1-2, p. 126-130, 2004. http://dx.doi.org/10.1590/S1517-83822004000100021

TÉLLEZ, S. J. et al. Evaluación de la calidad microbiológica del ostión de la "Laguna Madre" de Tamaulipas (México). Ciencia y Tecnología de los Alimentos, v. 2, n. 3, p. 152-157, 1999.

YOON, K. S. et al. A model of the effect of temperature on the growth of pathogenic and nonpathogenic Vibrio parahaemolyticus isolated from oysters in Korea. Food Microbiology, v. 25, p. 635-641, 2008. PMid:18541160. http://dx.doi.org/10.1016/j.fm.2008.04.007 